\title{
Os Redatores no Regime de Proibição de Acumular
}

Corsíndio Monteiro da Silva

\begin{abstract}
A Lei n 1.711 , de 28 de outubro de 1952 (Estatuto dos Funcionários Públicos Civis da Unnão), tem dois dispositivos que ensejaram, por muito tempo, controvérsias ou perplexidades em face do disposto no artigo 185 da Constituição Federal de 1946, assim expresso:
\end{abstract}

“Art. 185. É vedada a acumulação de quaisquer cargos, exceto a prevista no art. $96, \mathrm{n}^{\circ} \mathrm{I}$, e a de dois cargos de magistério ou a de um dêstes com outro técnico ou científico, contanto que haja correlação de matérias e compatibilidade de horário".

Ali estavam a norma geral de proibição de quaisquer cargos públicos e os casos de exceção, de cujo postulado resultou o artigo 188 da Lei $n^{\circ}$ 1.711, de 1952:

“Art. 188. É vedada a acumulação de quaisquer cargos.

Parágrafo único. Será permitida a acumulação:

I - De cargo de magistério, secundário ou superior, com o de juiz;

II - De dois cargos de magistério ou de um dêstes com outro técnico ou científico, contanto que em qualquer dos casos haja correlação de matérias e compatibilidade de horário".

Essas, as normas que consubstanciavam o regime de acumulação.

Eis que a própria Lei $n^{\circ} 1.711$, de 1952, assim dispunha no Título VI, Capítulo Û́nico: 
"Art. 246. Função de jornalista profissional não é incompativel com a de servidor público, desde que êste não exerça essa atividade na repartição onde trabalha".

"Art. 265. Para efeito do disposto no art. 7\% do Decreto-lei $n^{\circ} 7.037$, de 10 de novembro de 1944 , são considerados jornalistas os redatores do serviço público federal, como os da Agência Nacional.

Parágrafo único. O disposto neste artigo só se aplica aos profissionais devidamente registrados no Serviço de Identificação Profissional do Ministério do Trabalho, Indústria e Comércio, e aos portadores de diplomas expedidos pelo Curso de Jornalismo das $\mathrm{Fa}$ culdades de Filosofia, oficiais ou reconhecidas, desde que estejam sindicalizados, pelo menos até dois anos antes da vigência desta lei".

Complementando os dados: o artigo $7^{\circ}$ do Decreto-lei $n^{\circ} 7.037$, de 10 de novembro de 1944 , referido no artigo 265 do Estatuto dos Funcionários, assim dispunha:

"Art. 79 Não haverá incompatibilidade entre o exercício da profissão de jornalista e o de qualquer função remunerada, ainda que pública."

Fomos designados para relatar, na Comissão de Acumulação de Cargos, certo processo que cuidava da situação funcional de um Redator da Agência Nacional que pretendia continuar a exercer êsse cargo cumulativamente com outro de Procurador autárquico.

Apesar de vários pronunciamentos contrários a êsse tipo de acumulação não prevista nas regras de exceção à norma geral de proibição de acumular adotada na Constituição Federal e reproduzida na Lei $n^{\circ} 1.711$, de 28 de outubro de 1952, chegamos a participar da dúvida que passou a reinar com o tumulto criado por alguns entendimentos conspícuos que davam, inclusive, pela inconstitucionalidade daquele diploma legal, embora em abril de 1954, mal ingressávamos no DASP, emitiamos, um tanto quanto tìmidamente, pareceres contrários à acumulação de dois cargos de Redator ou de um de Redator com outro de natureza técnica ou científica ou mesmo administrativa. 
Passamos a integrar a Comissão de Acumulação de Cargos em maio de 1956, e até 1960 vimos aquêle órgão de deliberação coletiva manifestar-se contràriamente à acumulação de cargos quando um era de Redator e o outro não fôsse de magistério. Sempre se entendeu não ser possível admitir-se regra de exceção além daquelas previstas na Carta Magna.

Ainda assim, a Comissão de Acumulação de Cargos não enfrentara o problema, com o fixar uma norma geral que pudesse ser aplicada a todos os casos pendentes.

Ao recebermos referido processo para relatar, passamos a observar com atenção maior aquêles dispositivos acima enumerados, atentando para a sua letra, abstraindo-nos de qualquer idéia preconcebida. E verificamos que não havia razão maior para tanta celeuma ou, pelo menos, para tanta dúvida e perplexidade que na verdade existiam! Por isso é que dissemos que bastava "uma leitura mais atenta para êsses dispositivos legais que a mens legis desponta em uma clareza meridiana sem, absolutamente, entrar em conflito com as normas que constituem o regime de acumulação de cargos".

Nossa argumentação tôda se firmou na distinção entre o regime de acumulação de cargos, que é postulado constitucional, e um regime de incompatibilidade, matéria esparsa pela Carta Magna, pela legislação ordinária, pela jurisprudência.

Acentuamos, então, que o primeiro é assunto de mera conveniência administrativa e diz respeito a uma politica de administração; o segundo é matéria menos ponderável e que se situa no mundo ético.

O assunto, esclareça-se, foi examinado sob a égide da Constituição Federal de 18 de setembro de 1946.

Assim é que dissemos:

"Exemplo de incompatibilidades previstas na Constituição Federal de 1946 é o constante do artigo 48, que diz:

“Art. 48. Os deputados e senadores não poderão:

I - Desde a expedição do diploma:

a) celebrar contrato com pessoa jurídica de direi to público, entidade autárquica ou sociedade de economia mista, salvo quando o contrato obedecer a normas uniformes;

b) aceitar nem exercer comissão ou emprêgo remunerado de pessoa juridica de direito público, entidade 
autárquica, sociedade de economia mista ou emprêsa concessionária de serviço público;

II - Desde a posse:

a) ser proprietário ou diretor de emprêsa que goze de favor decorrente de contrato com pessoa juridica de direito público, ou nela exercer função remunerada; tido ad nutum;

b) ocupar cargo público do qual possa ser demi-

c) exercer outro mandato legislativo, seja federal, estadual ou municipal;

d) patrocinar causa contra pessoa jurídica de direito público". do mandato.

"A infração de qualquer dêsses dispositivos importa perda

"Embora o citado artigo 48 não designasse incompatibilidades a essas hipóteses proibidas, elas o são realmente, como é óbvio, tanto que o artigo 197 da mesma Constituição Federal assim dispõe:

"Art. 197. As incompatibilidades declaradas no art. 48 etc.".

"O mesmo assunto de incompatibilidade está previsto na Consituição Federal em seu artigo 96, que diz:

"Art. 96. É vedado ao juiz:

I - Exercer, ainda que em disponibilidade, qualquer outra função pública, salvo o magistério secundário e superior e os casos previstos nesta Constituição. sob pena de perda do cargo judiciário;

II - Receber, sob qualquer pretexto, percentagens, nas causas sujeitas a seu despacho e julgamento;

III - Exercer atividade politico-partidária".

"Quando a lei define qual a incompatibilidade, prevê, via de regra, a excludente, em artigo distinto, como nos casos dos artigos 49 e 51 da Constituição Federal, ou no corpo do mesmo dispositivo, como na hipótese da letra a, do item I, do artigo 48 , ou
no acima citado artigo 96 , item I.

"Dissemos que o artigo 48 da Constituição não se refere expressamente à palavra incompatibilidade mas que êsse dispositivo não cuida de outro assunto, tanto quanto o artigo 96 , acontecendo 
não raro, que o legislador confunde os dois institutos ou usa expressões impróprias como no caso do artigo 185 da Constituição, assim redigido:

"Art. 185. É vedada a acumulação de quaisquer cargos, exceto a prevista no art. $96, \mathrm{n}^{\circ} \mathrm{I}$, etc.".

“Ora, no referido artigo $96, \mathrm{n}^{\circ} \mathrm{I}$, não foi prevista senão uma exceção de incompatibilidade. Na mesma impropriedade incidiu o redator da Emenda Constitucional n? 20, de 25 de maio de 1966, que deu nova redação ao artigo 185 da Constituição Federal.

"Embora por vêzes o legislador trate de ambos os assuntos englobadamente, como no caso típico do artigo 185 da Constituição Federal, não é difícil dissociar mentalmente o que diz respeito à mera conveniência administrativa, o que se situa estritamente no âmbito da ética ou da independência dos podêres, ou o que participa dos dois institutos. Foi essa conveniência administrativa que fêz com que o Constituinte de 1946 fizesse uma ressalva à incompatibilidade do Juiz, para permitir que lecionasse; à do deputado ou senador que desempenhasse missão diplomática, participasse, no estrangeiro, de congressos, conferências e missões culturais, bem como fôsse investido em função de Ministro de Estado, Interventor Federal ou Secretário de Estado, sem perda do mandato. Foi essa conveniência administrativa que ensejou a Emenda Constitucional n² 20, de 25 de maio de 1966, no sentido de que dois cargos técnicos só seriam acumuláveis quando fôssem dois cargos destinados a Médicos.

"Ora, voltando ao fundamento legal do pedido, o artigo 246 da Lei n" 1.711, de 1952, diz: "Função de jornalista profissional não é incompativel com a do servidor público, desde que êste não exerça essa atividade na repartição onde trabalha". E o artigo $7^{\circ}$ do Decreto-lei $n^{\circ} 7.037$, de 1944 , a que se reporta o artigo 265 daquele diploma legal, diz igualmente: "Não haverá incompatibilidade entre o exercício da profissão de jornalista e o de qualquer função remunerada, ainda que pública".

"O servidor público, assim, pode ser jornalista, desde que exerça essa atividade fora da repartição onde trabalha. Se o Redator da Agência Nacional é considerado jornalista não está incompatibilizado de exercer um outro cargo público, porém isto não o coloca fora do regime de acumulação de cargos. Se o Re dator da Agência Nacional quiser exercer um outro cargo público em regime de acumulação, há que verificar se a situação se enquadra em uma das hipóteses constitucionais, isto é, se se trata - o cargo de Redator - de cargo de natureza técnica ou científica, dentro da definição do artigo $3^{\circ}$ do Decreto $n^{\circ} 35.956$, de 2 de agôsto de 1954 - o que já se pode dizer afirmativamente, em face de parecer do Sr. Consultor-Geral da República - e e o outro de magistério de matéria que tenha relação imediata e 
recíproca com as atribuições especificas do Redator, bem como que possam ser exercidos em horários que não se conflitem, que sejam compativeis.

"Dêsse modo, a nosso ver, aquêles dispositivos legais se referiram à inexistência de incompatibilidades entre função de jornalista profissional - que tal é a de Redator da Agência Nacional - com a do servidor público, não pretendendo, com isso, criar uma exceção a mais ao artigo 185 da Carta Magna, o que seria flagrantemente inconstitucional, ou excluir a hipótese do regime de "acumulação de cargos, o que daria no mesmo, em última análise".

O Professor José Medeiros, Presidente da Comissão de Acumulação de Cargos, sem discordar pròpriamente do nosso ponto-de vista, entendeu que, como o assunto devia ser submetido ao Sr. Consultor-Geral da República, em face de dúvidas ainda existentes, seria conveniente fazer - se um histórico do tratamento dado ao assunto, desincumbindo-se êle dessa tarefa, emitindo, à guisa de voto, um fidelíssimo histórico digno de sua inequivoca competência profissional.

Assim concluiu o Professor José Medeiros o seu voto:

"Contudo, quer se trate de aplicação da norma estatutária permanente (art. 246), quer se refira à execução da norma transitória (art. 265), os respectivos destinatários ficarão submetidos, quando ocorrer acumulação de cargos, aos princípios inscritos no artigo 185 da Constituição Federal. Isso porque, conforme demonstrou o ilustre Dr. Corsindio Monteiro da Silva, a hipótese é de declaração de inexistência de incompatibilidade e não de exceção à norma constitucional proibitiva de acumulação de cargos públicos".

Nosso ponto-de vista logrou sensibilizar a douta ConsultoriaGeral da República, havendo o eminente Professor Adroaldo Mesquita da Costa emitido o Parecer $n^{2} 470 \sim \mathrm{H}$, de 27 de janeiro de 1967, que foi aprovado, pelo Sr. Presidente da República. adotando integralmente a nossa tese. deslindando, assim, de uma vez por tôdas, na esfera administrativa, o verdadeiro affaire Redatores do Serviço Público em face do regime de proibição de acumu-
lar. (D. O . de 23-2-67).

Cumpre acentuar, por derradeiro, que se os nossos constituintes efetivamente quisessem colocar os Redatores em situação privilegiada quanto ao regime de acumulação de cargos públicos teriam tido muitas oportunidades para fazê-lo, inclusive por ocasião da elaboração da Carta de 1967. ( $\left.{ }^{*}\right)$

(*) Corsíndio Monteiro da Silva -. Assistente Juridico do DASP Membro da Comissão de Acumulação de Cargos (CAC). 